\title{
Social support for veterans taking part in military service outside their country's borders
}

Soldiers who return to their country of residence after military service are subject to numerous, mostly negative, effects linked to exposure to stress. Post-traumatic stress disorder is one of the most common anxiety disorders, one which develops as a result of being exposed to traumatic experiences, both psychological and physical. Post-traumatic stress disorder is also the main result of participation in active armed combat impacting war veterans, concerning mostly service undertaken outside their home country. Consequently, proper psychological preparation for armed combat, psychological support during service, as well as the support granted after soldiers return home, are of critical importance. This work characterises social support which is given to army personnel involved in armed combat. Methods of social involvement, which are provided to the soldiers taking part in military service outside their country, have also been described. The paper itself was written for two reasons: firstly, in order to exchange knowledge mainly in the areas of psychology and sociology; and secondly, to focus attention on those soldiers struggling with issues resulting from participation in military service outside their home country.

\section{KEY WORDS}

social support; types of social support; post-traumatic stress disorder; veteran 


\section{BACKGROUND}

Social support is the help accessible to an individual in difficult situations, and which is not limited only to material help. It has various qualifications and dimensions which are described in the available body of literature. Proper choice and application thereof depends on the situation and difficulties experienced by the supported individual (Sarason, 2013; Lin, Dean, \& Ensel, 2013). The most important source of such support appears to be the family and those close to the individual seeking help. However, the role of aid from formal and professional sources should not be underestimated. Everything depends on the individual and the types of support preferred by them.

Each individual holds distinct, personal immunity for intense emotional experiences. In many cases, difficult situations do not impact some individuals at all, but are the cause of depression or severe stress for others. Limits of stress resilience vary greatly among individuals. Exceeding one's limit will result in permanent marks on one's psyche. Sometimes, the impact of trauma passes on its own. In other cases, in which the stress symptoms are too strong, there is a possibility of developing a group of clinical symptoms, known as post-traumatic stress disorder (PTSD). PTSD is a mental disorder that can develop after a person is exposed to a traumatic event, such as sexual assault, warfare, traffic collisions, or other threats to a person's life. Symptoms may include disturbing thoughts, feelings, or dreams related to the events, mental or physical distress in response to trauma-related cues, attempts to avoid trauma-related cues, alterations in how a person thinks and feels, and an increase in the fight-or-flight response. These symptoms last for more than a month after the event (Sherin \& Nemeroff, 2011).

One of the professional groups most exposed to the effects of negative stress are soldiers taking part in armed combat outside their home country. Results of stress which arise during military service may last long after the army personnel return home. This is why it is of crucial importance for soldiers to receive professional help and support from the beginning, in order for them to recover.

The main aim of this paper is to analyse and explore the types of social support provided to veterans after their return from active service away from their homeland.

\section{SOCIAL SUPPORT PROVIDED TO SOLDIERS SERVING OUTSIDE THEIR HOME COUNTRY}

People who are most subjected to the effects of negative stress include soldiers participating in armed combat outside of their homeland. PTSD symptoms develop during such military service, but might last long after this service has finished. Army personnel exposed to such experiences often struggle with readjustment to their previous lifestyle. Often such individuals are overwhelmed by the situation, requiring understanding from friends and family, as well as social support. Even though soldiers who take part in modern military operations are aware of the possible difficulties which they may face, some of them still struggle with the aftermath. The challenge is to skilfully deal with these circumstances.

The Polish army's experience in military action outside its borders, e.g. in Yugoslavia, Iraq, and Afghanistan, has allowed for the determination of the range and stages of psychological support. It encompasses all soldier categories, namely soldiers, veterans in active service, retired veterans, army personnel, as well as their close family members (Gewirtz, Erbes, Polusny, Forgatch, \& DeGarmo, 2011; Verdeli et al., 2011; Goniewicz, Goniewicz, \& Pawłowski, 2016; Wloszczak-Szubzda, Jarosz, Goniewicz, \& Goniewicz, 2016; Balderrama-Durbin et al., 2013).

Adequate preparation for military service, including psychological preparations such as classes on how to cope with stress, are the basis of specialised training of each soldier qualified for participation in military service within the region of armed conflict. Its aim is to provide help for better functioning in serious armed combat conditions. Psychological protection is effective only if it is comprehensively provided before the soldier's departure, during their service, and after their return. Accomplishment of these tasks is the responsibility of numerous specialists in the fields of psychology, psychological prophylaxis consultation, psychological military workshops, as well as military and state health centres. Every psychologist who is qualified for service outside their country is obliged to take part in training which aims to prepare them to perform their duties during their service (Van Voorhees et al., 2018; Terziev, 2018; Donoho et al., 2018).

\section{PREPARATION FOR SERVICE ABROAD}

Preparation activities are undertaken before army personnel depart for the location of a military operation, and are preceded by preliminary elimination, as well as the selection of personnel who are suitable for performing extreme tasks. Psychological military workshops are responsible for these measures. Commanders also have the right to seek the opinion of a psychological prophylaxis consultant, so that they acquire knowledge concerning the psychological state of their subordinates who are to take part in military operations. Professional psychological assessment of the candidate is vital, as a lack of which may result in the triggering or intensification of psychological disorders caused by the difficult work conditions. Proper care of the endurance and health of the candidate is 
also significant (Pexton, Farrants, \& Yule, 2018; Harrington-LaMorie, Jordan, Ruocco, \& Cerel, 2018).

The preparation of the candidate's family is as important as the candidate's own training. Families may use psycho-education, which prepares them for the separation, and seek psychological consultations. Commanders also organise meetings for those departing and their families, which are attended by chaplains and psychologists who provide support for those staying in the country. During these meetings, information concerning the place and the character of their function, possible contact with those departing, or potential help provided, is given. As a consequence of such meetings, the families of the soldiers have the sense that after their departure, they can count on support. However, soldiers themselves may also influence the feelings of their families. Each departing soldier must understand that they have the main impact on how the separation will influence all those involved (Tubbs, Young, Heath, \& Dyches, 2019).

\section{PSYCHOLOGICAL PROTECTION DURING SERVICE}

Psychological protection was first provided to Polish soldiers during the campaign in Yugoslavia in 2000. During armed operations, there is little or no time to carry out systematic psychological training. One training session is performed during a shift rotation. The psychologist who finishes their service carries out integrating activities with their successor and the groups which have not trained together before departure. Information concerning the place and time of psychological consultation is conveyed, and an appropriate telephone number is provided (Elcheroth \& Spini, 2009).

During service, the psychologist actively takes part in the implementation of the contingent's tasks, which include: meeting organisation and support for soldiers who have experienced traumatic situations; individual and group work in the case of mourning; giving advice and support to soldiers in the case of separation; organising individual sessions; establishing documentation of their work; cooperation with doctors, chaplains, pedagogical officers and commanders; organisation of meetings in subdivisions, which tackle current issues; support for commanders for resolving conflicts.

The psychologist-soldier can also take part in departures of convoys providing humanitarian and medical aid, for better integration, and in order to provide the opportunity to observe soldiers and their behaviour during task implementation. What is more, they attend briefings, which enable them to possess current knowledge of the situation of army personnel. The psychologist has a dedicated position, one where those in need of help may contact them. There is a landline telephone, with a number solely dedi- cated to the psychologist. The psychologist also has a dedicated mobile phone, in case they are away from their office. An important role in the case of a traumatic experience may also be played by a chaplain, whose main task is to provide spiritual support for soldiers involved in military service abroad. But the most significant role belongs to the commanders, as they are the most responsible for the psychological condition of their subordinates (Campbell \& Riggs, 2015; Moelker, Andres, Bowen, \& Manigart, 2015).

Before a military operation is over, the psychologist prepares the soldiers for their return home by organising group activities or conducting individual talks. They usually concern behaviour or psychological states which might occur just after arriving home, the functioning of the family, and conditions for quicker readjustment (Raskind et al., 2018). During a soldier's absence, families might use the help of the Family Support Centre, which provides psychological, legal, logistic or other types of help, depending on existing needs. Families undergo prophylaxis treatments which are intended to reduce and counter the negative effects of separation, and projects aimed at integration within their environment.

The Family Support Centre (FSC) is created on the basis of the military unit. The unit commander appoints its manager and duty personnel, and approves the work schedule of the FSC. In the FSC headquarters there is a room where access to the internet and telephone contact between soldiers and their families is provided. There is also a room for officers on duty. It functions as long as there is a need, not shorter than the change of Polish Army Contingent lasts, which involves participation of soldiers of a given military unit or garrison.

The commander of the contingent, in case of the event of life or health risk, or which results in casualties or fatalities, sets up a Crisis Intervention Group, consisting of a doctor, a psychologist, and a chaplain. The group stays with those affected for as long as they need support. Its main goal is to aid them in dealing with emotions. It also assesses whether the peer support is sufficient for the participants of the event, and whether it is necessary to apply additional crisis intervention methods. The decision of the psychologist and doctor may result in temporary removal of the soldier from their tasks, or medical rotation to their country, which may cause psychological disorders evoked by severe stress.

In case of a soldier's death during military service outside their homeland, the Notifying Team, consisting of the commander (or their representative), a psychologist, doctor, chaplain and a person responsible for communication with the family, is sent to the victim's family immediately. The role of the team is to deliver the information, and provide support in such a difficult time (Netczuk-Gwoździewicz, 2018; Karakiewicz, Rozmarynowska, Paszkiewicz, \& Zabielska, 2018).
Social support for veterans 


\section{PROPHYLAXIS AND CONTROL AFTER MILITARY SERVICE}

It often happens within army personnel that a return to normal professional and family life in their home country after overseas service causes a lot of difficulties. Social support proves to be crucial when it comes to overcoming these problems. However, sometimes even such support is not enough to deal with the emerging issues. Therefore, the role of a psychiatrist or psychologist is vital.

After their return, soldiers are immediately referred to a psychologist by their commander. There, they are informed about the possible difficulty in readaptation to normal life, the possible problems of alcohol addiction, family problems, relationship problems, as well as accessible aid means. Psychological protection after military service should be provided long term, as potential negative reactions to traumatic events can be triggered with considerable delays (Wróbel, 2017).

Families of soldiers who take part in overseas military service are prepared in advance for their return. There are meetings organised beforehand by the Family Support Centre. In order to reach as many in need as possible, the centre distributes leaflets among soldiers, which are meant to be passed onto their families. Information spread this way helps to recognise the symptoms of PTSD, as well as other function disorders, and recommend manners and possibilities of receiving specialised help. Families may seek help directly from a psychologist in a military unit, psychologist workshop or a military hospital. All army employees and soldiers who have any type of problems with health or mental disorders after service have the chance of treatment in a chosen health facility, free of charge. The best facilities to provide such help are military health centres, which specialise in treatment of disorders linked to combat and operational stress (Goniewicz, Goniewicz, \& Burkle, 2019; Pawłowski, Goniewicz, Goniewicz, Czerski, \& Lasota, 2018a, 2018b).

Soldiers are also sent to professionally set up prophylaxis-treatment tours organised by national health care. Such therapy consists of 14-day antistress training, during which soldiers may use a wide range of relaxation-rehabilitation treatments, group classes, rehabilitation treatments, relaxation, and psycho-educational sessions. Participation in such a tour allows for a calm, stress-free and smooth transition into everyday life, as well as fast regeneration. Moreover, the additional benefit is spending time with family, or even inviting a companion to the training. Training sessions teach their participants how to deal with stress, and allow for the reconstruction of emotional relationships with family members. The subject of negative emotions caused by traumatic situations during military service is discussed dur- ing the sessions. Individual psychological help is also available during the tour (Marchewka, 2017).

Treatment of the symptoms caused by combat stress depend on the tenacity and intensity of such stresses, as well as the specific individual. If the symptoms are much more severe, such as severe insomnia, anxiety disorders and depression, and the psychotherapy does not bring results on its own, there is a need for pharmacological treatment. Pharmacological treatment is usually provided as a supplementary measure, and is meant to deal with symptoms. In order to decrease the intensity of PTSD, mood stabilising medicine, selective serotonin reuptake inhibitors (SSRI), and selective serotonin/noradrenaline reuptake inhibitors (SNRI) are used. These medicines are intended to increase the levels of neurotransmitters in the brain, and are used in treating depression, anxiety disorder, social phobias or PTSD (Lasota, Goniewicz, Goniewicz, \& Czerski, 2018; Goniewicz, Goniewicz, \& Lasota, 2018).

Sometimes social support is not enough for the soldier to deal with the stigma of war. Some of them seek a psychologist or other type of specially trained professional in order to function properly within society, or seek any other available level of support. Victims often need to deal with the stigma which is associated with being diagnosed with psychological disorders. Such stigma is especially prevalent among particular social groups, for example, the army. The fear of stigmatisation might be revealed in trivial situations, such as the unease linked to those within the soldier's social environment finding out about their psychological or psychiatric consultations. They do not wish to be deemed as weaker or inferior in the eyes of others. Some soldiers also believe that admitting to complications caused by armed combat might influence their further army career, and end up taking to alcohol, drugs or medicine, instead of seeking professional help. Stigmatisation of soldiers who use these forms of support will continue while mental health issues are thought of as a sign of imbalance, defectiveness or moral weakness (Steenkamp, Litz, Hoge, \& Marmar, 2015; Weathers et al., 2018; Mobbs \& Bonanno, 2018).

\section{DISCUSSION}

Immediately after returning from military service, soldiers are sent to a psychologist by their unit commander, and are also informed about possible aid measures, assistance in dealing with legal matters and information about benefits they are entitled to. Veterans may use various forms of support provided by groups and institutions supporting soldiers in dealing with diverse kinds of psychological problems. These may include discussing their problems with an army chaplain, one who took part in the same military operations as they did, taking part in professional prophylaxis-treatment tours organised by national health 
care, etc. (Currier, Drescher, Holland, Lisman, \& Foy, 2016). However, in spite of the large number of possible aid types, veterans rarely decide to take advantage of them. This may be due to the fear of stigmatisation by other soldiers or supervisors. They are afraid that receiving any type of help, other than emotional support, might be seen as a sign of weakness, and will discredit them in the eyes of their colleagues (Norman, Haller, Hamblen, Southwick, \& Pietrzak, 2018). Situations in which veterans are faced with a lack of acceptance or rejection by the army personnel, coworkers and commanders, should be reduced and eliminated (Bovin et al., 2016; Elliott, Gonzalez, \& Larsen, 2011; Sautter, Armelie, Glynn, \& Wielt, 2011).

Peer support for those facing similar circumstances facilitates a faster and more positive return to health. Therefore, due to their profession and participation in armed combat outside their homeland, veterans can share their memories regarding military service with others, which may allow for a faster return to normality, to the life they led before departing. Social support plays a key role in psychological health recovery of veterans suffering from PTSD. It allows for post-traumatic adaptation, assimilation of memories linked to stressful events, the search for meaning, as well as the acceptance of trauma. Support also plays a preventative role, protecting from trauma's effects, a lack thereof possibly leading to a strengthening of PTSD symptoms. Relatives and partners of veterans should be aware that they constitute one of the most important sources of support, and in many cases the most vital source.

\section{CONCLUSIONS}

As a result of the analysis of theoretical presumptions, it was found that social support is aid available in the unit in a crisis situation, which may be received by belonging to a unit of a given social network. There are various criteria and dimensions of the support's divisions, the most important being the division into social, structural and functional support. There are three main sources of social support: personal, formal and professional. The types of used support depend on circumstances and experienced difficulties. It may be emotional, informational, instrumental, material, spiritual support, as well as viewed and received support.

When it comes to the need for receiving social support, it may be claimed that the group most at risk of the impact of negative stress is that of soldiers taking part in active military service outside their home country. Appropriate psychological preparation of military personnel before this service, psychological protection during the service, and the aid provided after a soldier's return, are key to ensuring minimisation of the negative effects of a traumatic event.

\section{REFERENCES}

Balderrama-Durbin, C., Snyder, D. K., Cigrang, J., Talcott, G. W., Tatum, J., Baker, M., \& Smith Slep, A. M. (2013). Combat disclosure in intimate relationships: Mediating the impact of partner support on posttraumatic stress. Journal of Family Psychology, 27, 560-568. https://doi.org/10.1037/a0033412

Bovin, M. J., Marx, B. P., Weathers, F. W., Gallagher, M. W., Rodriguez, P., Schnurr, P. P., \& Keane, T. M. (2016). Psychometric properties of the PTSD checklist for diagnostic and statistical manual of mental disorders - fifth edition (PCL-5) in veterans. Psychological Assessment, 28, 1379-1391. https://doi.org/10.1037/pas0000254

Campbell, R., \& Riggs, S. A. (2015). The role of psychological symptomatology and social support in the academic adjustment of previously deployed student veterans. Journal of American College Health, 63, 473481. https://doi.org/10.1080/07448481.2015.1040408

Currier, J. M., Drescher, K. D., Holland, J. M., Lisman, R., \& Foy, D. W. (2016). Spirituality, forgiveness, and quality of life: Testing a mediational model with military veterans with PTSD. International Journal for the Psychology of Religion, 26, 167-179. https:// doi.org/10.1080/10508619.2015.1019793

Donoho, C. J., LeardMann, C., O'Malley, C. A., Walter, K. H., Riviere, L. A., Curry, J. F., \& Adler, A. B. (2018). Depression among military spouses: Demographic, military, and service member psychological health risk factors. Depression and Anxiety, 35, 1137-1144. https://doi.org/10.1002/da.22820

Elcheroth, G., \& Spini, D. (2009). Public support for the prosecution of human rights violations in the former Yugoslavia. Peace and Conflict: Journal of Peace Psychology, 15, 189-214. https://doi.org/10. 1080/10781910902837321

Elliott, M., Gonzalez, C., \& Larsen, B. (2011). US military veterans transition to college: Combat, PTSD, and alienation on campus. Journal of Student Affairs Research and Practice, 48, 279-296. https://doi. org/10.2202/1949-6605.6293

Gewirtz, A. H., Erbes, C. R., Polusny, M. A., Forgatch, M. S., \& DeGarmo, D. S. (2011). Helping military families through the deployment process: Strategies to support parenting. Professional Psychology: Research and Practice, 42, 56-62. https://doi.org/10.1037/a0022345

Goniewicz, K., Goniewicz, M., \& Burkle, F. M. (2019). The Territorial Defence Force in disaster response in Poland: Civil-military collaboration during a state of emergency. Sustainability, 11, 487. https://doi. org/10.3390/su11020487

Goniewicz, K., Goniewicz, M., \& Lasota, D. (2018). Armed forces operation in the scope of the civilian health protection during peacekeeping and stabilization missions: A short review. Safety \& Defense, 4, 27-30.

Goniewicz, K., Goniewicz, M., \& Pawłowski, W. (2016). Protection of medical personnel in contemporary armed conflicts. Wiadomosci Lekarskie, 69, 280-284.
Social support for veterans 
Harrington-LaMorie, J., Jordan, J. R., Ruocco, K., \& Cerel, J. (2018). Surviving families of military suicide loss: Exploring postvention peer support. Death Studies, 42, 143-154. https://doi.org/10.1080/074 81187.2017.1370789

Karakiewicz, B., Rozmarynowska, B., Paszkiewicz, M., \& Zabielska, P. (2018). Psychosocial aspects of participation of the Polish Armed Forces in combat missions. Psychiatria Polska, 52, 873-886. https:// doi.org/10.12740/PP/OnlineFirst/75666

Paulina Mendrek, Beata Osiak, Krzysztof Goniewicz

Lasota, D., Goniewicz, K., Goniewicz, M., \& Czerski, R. (2018). Analysis of the professional burnout syndrome in selected groups. Journal of Education, Health and Sport, 8, 81-96. https://doi.org/10.5281/ zenodo. 1298362

Lin, N., Dean, A., \& Ensel, W. M. (Eds.). (2013). Social support, life events, and depression. Orlando, FL: Academic Press.

Marchewka, M. (2017). Injured veterans. The reality of life after returning from a mission. Ekonomia. Wroctaw Economic Review, 23, 113-120.

Mobbs, M. C., \& Bonanno, G. A. (2018). Beyond war and PTSD: The crucial role of transition stress in the lives of military veterans. Clinical Psychology Review, 59, 137-144. https://doi.org/10.1016/j.cpr.2017.11.007

Moelker, R., Andres, M., Bowen, G., \& Manigart, P. (Eds.). (2015). Military Families and War in the 21st Century: Comparative Perspectives. London, New York: Routledge.

Netczuk-Gwoździewicz, M. (2018). Consequences of chronic stress-related functioning of soldiers participating in missions. Zeszyty Naukowe SGSP/ Szkota Gtówna Stużby Pożarniczej, 65, 147-160.

Norman, S. B., Haller, M., Hamblen, J. L., Southwick, S. M., \& Pietrzak, R. H. (2018). The burden of co-occurring alcohol use disorder and PTSD in US Military veterans: Comorbidities, functioning, and suicidality. Psychology of Addictive Behaviors, 32, 224-229. https://doi.org/10.1037/adb0000348

Pawłowski, W., Goniewicz, K., Goniewicz, M., Czerski, R., \& Lasota, D. (2018a). Emergency Medical Services in Poland during mass events and disasters-competence and challenges. Journal of Education, Health and Sport, 8, 396-404. https://doi. org/10.5281/zenodo. 1237574

Pawłowski, W., Goniewicz, K., Goniewicz, M., Czerski, R., \& Lasota, D. (2018b). Administrative role in supporting the Emergency Medical System in disasters. Journal of Education, Health and Sport, 8, 11-21. https://doi.org/10.5281/zenodo.1236930

Pexton, S., Farrants, J., \& Yule, W. (2018). The impact of fathers' military deployment on child adjustment. The support needs of primary school children and their families separated during active military service: A pilot study. Clinical Child Psychology and Psychiatry, 23, 110-124. https://doi.org/10.1177/1359104517724494

Raskind, M. A., Peskind, E. R., Chow, B., Harris, C., DavisKarim, A., Holmes, H. A., Hart, K. L., McFall, M.,
Mellman, T. A., Reist, C., Romesser, J., Rosenheck, R., Shih, M. C., Stein, M. B., Swift, R., Gleason, T., Lu, Y., \& Huang, G. D. (2018). Trial of prazosin for posttraumatic stress disorder in military veterans. New England Journal of Medicine, 378, 507-517. https://doi. org/10.1056/NEJMoa1507598

Sarason, I. G. (Ed.). (2013). Social support: Theory, research and applications (Vol. 24). Berlin: Springer Science \& Business Media.

Sautter, F. J., Armelie, A. P., Glynn, S. M., \& Wielt, D. B. (2011). The development of a couple-based treatment for PTSD in returning veterans. Professional Psychology: Research and Practice, 42, 63-69. https:// doi.org/10.1037/a0022323

Sherin, J. E., \& Nemeroff, C. B. (2011). Post-traumatic stress disorder: the neurobiological impact of psychological trauma. Dialogues in Clinical Neuroscience, 13, 263-278.

Steenkamp, M. M., Litz, B. T., Hoge, C. W., \& Marmar, C. R. (2015). Psychotherapy for military-related PTSD: a review of randomized clinical trials. JAMA, 314, 489-500. https://doi.org/10.1001/jama.2015.8370

Terziev, V. (2018). Possible aspects of occupational and psychological adaptation of the military, discharged from military service and their families to a new activity life cycle. IJASOS - International E-journal of Advances in Social Sciences, 4, 786794. https://doi.org/10.18769/ijasos.477608.

Tubbs, A., Young, E. L., Heath, M. A., \& Dyches, T. T. (2019). Military deployment in a family: Children's literature as a basis for counseling support. Reading Horizons: A Journal of Literacy and Language Arts, 58, 75-99.

Van Voorhees, E. E., Wagner, H. R., Beckham, J. C., Bradford, D. W., Neal, L. C., Penk, W. E., \& Elbogen, E. B. (2018). Effects of social support and resilient coping on violent behavior in military veterans. Psychological Services, 15, 181-190. https:// doi.org/10.1037/ser0000187

Verdeli, H., Baily, C., Vousoura, E., Belser, A., Singla, D., \& Manos, G. (2011). The case for treating depression in military spouses. Journal of Family Psychology, 25, 488-496. https://doi.org/10.1037/a0024525

Weathers, F. W., Bovin, M. J., Lee, D. J., Sloan, D. M., Schnurr, P. P., Kaloupek, D. G., Keane, T. M., \& Marx, B. P. (2018). The Clinician-Administered PTSD Scale for DSM-5 (CAPS-5): Development and initial psychometric evaluation in military veterans. Psychological Assessment, 30, 383-395. https://doi. org/10.1037/pas0000486

Wloszczak-Szubzda, A., Jarosz, M. J., Goniewicz, M., \& Goniewicz, K. (2016). Evaluation of communication and acceptance of the patients by medical personnel. Roczniki Państwowego Zakładu Higieny, 67, 427-433.

Wróbel, I. (2017). Prospects of Territorial Defence Forces and Public Administration collaboration in terms of fighting natural disasters. Bezpieczeństwo. Teoria i Praktyka, 28, 133-150. 